\title{
BIULETYN POLONIJNY (74)
}

ZAWARTOŚĆ: I. Kardynał Józef Glemp w posłudze prymasowskiej dla Polonii i Polaków w świecie (Szkice wokół idei); II. Wizyty papieża Jana Pawła II w byłych republikach ZSRR a stosunki międzyetniczne; III. Orzeł i Lew - Polacy w Etiopii.*

\section{KARDYNAŁ JÓZEF GLEMP W POSŁUDZE PRYMASOWSKIEJ DLA POLONII I POLAKÓW W ŚWIECIE (SZKICE WOKÓŁ IDEI)}

Wymowne są słowa bulli nominacyjnej, która stała u początków posługi prymasowskiej kard. Józefa Glempa: „Zważywszy, że stolice metropolitalne gnieźnieńska i warszawska, w jednej osobie złączone, przez zgon umiłowanego śp. Księdza Kardynała Stefana Wyszyńskiego straciły swego pasterza - postanowiliśmy na czele wymienionych archidiecezji postawić Ciebie, Czcigodny Bracie, jako że poznaliśmy Twoje niezwykłe zalety umysłu i serca oraz gorliwość w pracy duszpasterskiej, okazaną na stolicy warmińskiej. Wobec tego - na mocy pełni Naszej Władzy Apostolskiej zwalniamy Cię z obowiązków w diecezji warmińskiej i mianujemy Cię Arcybiskupem Kościołów gnieźnieńskiego i warszawskiego, które na ten raz znowu w jednej osobie łączymy; równocześnie nadajemy $\mathrm{Ci}$ prawa i nakładamy obowiązki, które do tej wysokiej godności i do tego odpowiedzialnego urzędu należą" (Watykan, 3 VII 1981 r.).

\section{Opieka nad duszpasterstwem Polonii na całym świecie}

Dzięki specjalnemu pełnomocnictwu Stolicy Apostolskiej, kard. Józef Glemp od początku swej posługi przejął po kard. Auguście Hlondzie, abp. Józefie Gawlinie i później, Prymasie Tysiąclecia, kard. Stefanie Wyszyńskim, opiekę nad duszpasterstwem Polonii. „Jak Państwo wiecie - mówił kard.

* Redaktorem Biuletynu polonijnego jest Eugeniusz S a k o w i c z, Warszawa. 
J. Glemp na spotkaniu z Polonią Belgii - jest wielką tradycją prymasów Polski, że opiekują się wszystkimi emigrantami polskimi. Podjąłem i ja to zadanie" (Liege, Belgia, 22 II 1987 r.). Nowy prymas powołał jednocześnie swego delegata w osobie bp. Władysława Rubina (który był później sekretarzem generalnym Synodu Biskupów, kardynałem i prefektem Kongregacji Kościołów Wschodnich), a następnie bp. Szczepana Wesołego (później arcybiskupa tytularnego), pracujących przy Centralnym Ośrodku Duszpasterstwa Emigracyjnego w Rzymie. Struktura ta funkcjonowała do przejścia na emeryturę abp. Szczepana Wesołego i powołania bp. Ryszarda Karpińskiego, który w latach 2003-2008 pełnił funkcję delegata Konferencji Episkopatu Polski ds. duszpasterstwa emigracji polskiej oraz był przewodniczącym Komisji Episkopatu ds. Polonii i Polaków za Granicą. Kolejnym delegatem był (2009-2011) bp Wojciech Polak; obecnie jest nim (od 2011 r.) bp Wiesław Lechowicz. Tym samym, w jakimś sensie, wówczas zamknięta została ważna karta posługi prymasowskiej wobec Polonii.

Mówiąc o rodakach poza granicami ojczyzny warto przywołać słowa Ojca Świętego Jana Pawła II: „To, co mówię, płynie z żywego poczucia historii. Wy, którzy stworzyliście dzisiejszą Polonię brytyjską, jesteście dla mnie nie przede wszystkim emigracją, ale przede wszystkim żywą częścią Polski, która nawet wyrwana z ojczystej gleby nie przestaje być sobą. Owszem, żyje przeświadczeniem, że w niej właśnie, w tej części, w szczególny sposób żyje całość" (Londyn, 30 V 1982 r.). To jest pewne wskazanie pasterskie spojrzenia na fenomen bycia i życia poza granicami Polski. Przecież Polska „to ojczyzna tego człowieka, który dzisiaj stał się apostołem narodów i przemierza kontynenty, nauczając wszystkich" (Charleroi, Belgia, 22 II 1987 r.). W takie rozumienie Polonii wpisuje się m.in. tytuł książki prymasa Polski poświęcony jego wizycie duszpasterskiej w Wielkiej Brytanii: Boże, coś Polskę postat nad Tamizę. Wizyta duszpasterska w Wielkiej Brytanii 21 II - 4 II 1985 (Poznań 1988).

W praktyce prymasowi Polski bezpośrednio podlegały (i dziś nadal podlegają) Polskie Misje Katolickie (m.in. takich krajach jak: Anglia i Walia, Francja, Hiszpania, Argentyna, Australia i Republika Południowej Afryki) oraz inne ośrodki duszpasterstwa polonijnego (m.in. w Austrii, Włoszech, Szwajcarii). Struktury duszpasterstwa dla Polaków czy ludności polskiego pochodzenia mieszczą się zawsze $\mathrm{w}$ ramach pracy poszczególnych krajowych czy regionalnych konferencji episkopatów, a duszpasterze ściśle współpracują z nimi. Podejmują działalność przede wszystkim w duchu ogólnych wskazań Stolicy Apostolskiej. Prymas Polski nie ma zatem władzy 
jurysdykcyjnej nad katolikami poza granicami ojczyzny, gdyż ona zależy od lokalnych władz kościelnych różnego szczebla, np. w Anglii i Walii czy Francji - od tamtejszych konferencji episkopatu. Prymas Polski ma jednak wpływ, w imieniu episkopatu Polski, na obsadzanie funkcji rektora poszczególnych misji.

Kardynał Józef Glemp był bezpośrednim, z ramienia Konferencji Episkopatu Polski, przełożonym polskich instytucji w Rzymie: Papieskiego Kolegium Polskiego, Papieskiego Instytutu Polskiego, Papieskiego Instytutu Studiów Kościelnych oraz Polskiego Seminarium w Paryżu. Dwie pierwsze rzymskie instytucje podlegają jurysdykcji Stolicy Apostolskiej.

Kardynał J. Glemp, jako prymas Polski i duszpasterz wszystkich Polaków, odwiedzał rodaków w odległych krajach, zapalał wśród nich światło Ewangelii, zachęcał do zgody i wytrwania w wierze ojców i tradycji wyniesionej z kraju pochodzenia. Krzepił serca uciśnione niewolą i biedą na dalekiej Syberii i ludzi żyjących w oddaleniu oraz samotności. W swym pierwszym Orędziu do Polonii mówił: „Duch jedności i pokoju niech rządzi również Waszym życiem, Siostry i Bracia, aby nie było wśród Was opuszczonych i chodzących w samotności. Zrozumienie i braterstwo wśród Polaków są nie tylko nakazem chwili, lecz również powinny być błogosławionym owocem tradycji narodu od tysiąca lat Chrystusowego" (życzenia dla Polonii, Warszawa, 1981).

Oczywiste jest, że „nasi Rodacy są wszędzie. Odwiedzam ich, gdy tylko mogę. (...) Otóż takich spotkań mam bardzo dużo. Polacy są na całym świecie" (Algier, Algieria, 16 I 1987 r.). Prymas Polski potwierdzał, że zadanie to jest trudne, ale chętnie przezeń podejmowane i dające pewną satysfakcję.

Na drodze spotkań z Polonią, już jako biskup warmiński, J. Glemp był w Stanach Zjednoczonych, Kanadzie, Francji i Republice Federalnej Niemiec. Jednak dopiero jako duchowy opiekun duszpasterstwa polskiej emigracji prymas Polski szczególnie chętnie odwiedzał liczne środowiska polonijne w różnych krajach świata, niemal na wszystkich kontynentach. Faktycznie zapoczątkowała je prawie trzytygodniowa wizyta duszpasterska w Brazylii i Argentynie (1984). Prymas przemierzał drogi wśród Polonii, idąc w pewnym sensie śladami kard. A. Hlonda.

Z kolejnych wizyt duszpasterskich warto wskazać te, które miały miejsce w następujących państwach: Austria (1983), Węgry (1983), Kanada (1986), Belgia (1987), Norwegia i Szwecja (1987), Irlandia (1988), Australia i Nowa Zelandia oraz Filipiny (1988), Rumunia (1992), Meksyk (1993), Szwajcaria (1994), Republika Południowej Afryki (1997), Norwegia (2000). Kardynał 
J. Glemp mówił w czasie jednej z wizyt: „Tak się składa, że my, Polacy, jesteśmy rozproszeni po wielu krajach. Mam możność odwiedzać naszą Polonię i zawsze dostrzegam ten sam obraz wierności dla Polski. Ta wierność najlepiej bywa utrzymywana przez tych, którzy złączeni są z Kościołem. Wiemy, że nie wszystkim udaje się tę więź utrzymać. Niektórzy z Kościołem nie byli związani, niektórzy o więzi z Kościołem zapomnieli, czasem więzi te się rozluźniły. Tak jest u nas, tak jest za granicą" (Overijse, Belgia, 21 II 1987 r.).

W tych spotkaniach kształtowały się i rozwijały główne nurty teologicznego widzenia Rodaków poza krajem oraz świadomość zobowiązań kraju pochodzenia wobec nich. Ten ostatni element nie zawsze był dostrzegany. Kardynał J. Glemp aktualizował zawsze swe przesłanie kierowane do Polonii, dotyczące miejsca, środowiska czy uwarunkowań ich życia. Prymas Polski wskazywał: „Przede wszystkim jestem wdzięczny Polonii za jej postawę i duchową, i narodową, za uznanie, jakim się cieszy wśród społeczeństwa (...). Wiele osób ma pozycje znaczące, a więc jest to znak, że są cenione, wykształcone, że pracują" (Liege, Belgia, 22 II 1987 r.).

W ciągu lat prymasowskiej posługi kard. J. Glemp kilkakrotnie gościł - jak już wspomniano - wśród Polaków zamieszkałych we Francji i Włoszech, w Wielkiej Brytanii, Republice Federalnej Niemiec (był także w Niemieckiej Republice Demokratycznej), Stanach Zjednoczonych. Te wspólnoty, choćby ze względu na liczebność i znaczenie, także społeczno-polityczne (np. prezydent i rząd emigracyjny w Londynie), stały się miejscem szczególnego pogłębiania się teologii polonijnej, teologii wydarzenia i miejsca rodaków poza granicami i Polaków w kraju.

\section{Wśród rodaków na Wschodzie}

Szczególnego znaczenia nabrały wyjazdy duszpasterskie prymasa Polski do rodaków na Wschodzie, na tereny byłego Związku Socjalistycznych Republik Radzieckich. Na początku posługi prymasowskiej było to niemożliwe. Kardynał J. Glemp zauważał: „Mówiąc o Polonii, myślimy zawsze o Polakach w Ameryce, Niemczech, Belgii, we Francji. Nie dostrzegamy często tych naszych braci, którzy są poza wschodnimi granicami Polski. A przecież wyrastają oni z tego samego pnia" (Overijse, Belgia, 21 II 1987 r.). Kard. J. Glemp odwiedził Rosję, Ukrainę, Białoruś, Litwę, Łotwę, Estonię i Kazachstan. Brał udział w uroczystościach jubileuszowych tysiącleciu Chrztu Rusi, jako członek oficjalnej delegacji Stolicy Apostolskiej 
(Moskwa-Kijów, 7-15 VI 1988 r.). Spotkał się wówczas w Zagorsku z patriarchą Pimenem.

W jednym z wywiadów prymas Glemp dzielił się swoją radością: „Ja sam miałem możność dotarcia do Polaków w dawnych krajach Związku Radzieckiego i zapoznania się z ich postawami duchowymi. To nie jest Polonia! Są to Polacy mieszkający na obszarach azjatyckich Rosji i we wschodniej Europie. Odwiedziłem ich jeszcze w czasach ZSRR. Pamiętam spotkania w Moskwie, na Białorusi, na Syberii, w Kazachstanie. (...) Ci Polacy zostawiają głęboki ślad nie tylko kultury polskiej, ale i duchowości, łącznie $\mathrm{z}$ wiarą, która w ich przypadku bardzo mocno się identyfikuje z narodowością" (13 XII 2009 r.).

W 1988 r. prymas Polski odwiedził Białoruś (5-7 IX 1988 r.), która to wizyta była wielką misją ewangelizacyjną i zarazem ekumeniczną. Praktycznym jej efektem były m.in. decyzje skierowania na Białoruś około stu kapłanów do pracy duszpasterskiej, nie tylko wśród ludności polskojęzycznej. Kardynał J. Glemp był wówczas m.in. w Grodnie, Lidzie, Nowogródku, Mińsku, Nieświeżu, Pińsku i Brześciu. Było to szczególne doświadczenie świadectwa wiary żyjących tam Polaków.

W maju 1990 r. kard. J. Glemp, jako legat Ojca Świętego Jana Pawła II, przewodniczył obrzędom żałobnym kard. J. Waivodsa w Agona na Łotwie, a także odwiedził inne centra religijne Łotwy oraz Litwy, m.in. Ostrą Bramę w Wilnie (28-29 V 1990 r.). To ostatnie miejsce zapisało się szczególnie żywo w jego pamięci.

W dniach 4-12 VIII 1992 r. prymas Polski był ponownie w Moskwie i Kazachstanie, gdzie przybył z wizytą duszpasterską i ekumeniczną. Spotkał się wówczas z patriarchą Aleksym II. Celebrował Eucharystię dla społeczności katolickiej w Moskwie, na schodach kościoła Niepokalanego Poczęcia Najświętszej Maryi Panny. Dopiero 12 VIII 1999 r. kościół ten definitywnie powrócił do społeczności katolickiej, dzięki zaangażowaniu w jego odzyskanie kard. Angelo Sodano, sekretarza stanu Stolicy Apostolskiej.

Dla prymasa Polski szczególnie wzruszające były spotkania w Kazachstanie z wyjątkowo doświadczonymi rodakami, zwłaszcza ofiarami dramatu zsyłek-przesiedleń z Ukrainy w czasach stalinowskich. Wspólna modlitwa połączona była z licznymi znakami jedności ekumenicznej, tak cenionej w tym wieloreligijnym kraju.

Kolejne spotkania z rodakami odbyły się na Łotwie i Litwie, w czasie wizyty papieskiej (4-9 IX 1993 r.). Kardynał J. Glemp modlił się w Ostrej 
Bramie. Szczególnym akcentem było nawiedzenie cmentarza na Rossie. Z kolei wizyta na Białorusi, wraz z ponownym poświęceniem katedry w Mińsku (20-22 X 1997 r.) oraz obecność prymasa Polski w Sankt Petersburgu (13-16 VI 1998 r.), była znakiem świadectwa wiary (przez poprowadzenie procesji Bożego Ciała, modlitwę za rzesze pomordowanych czy ofiary II wojny światowej oraz odwiedzenie licznych zabytków architektury, sztuki i nade wszystko miejsc kultu religijnego).

Szczególnie wymowny charakter miała pielgrzymka przez Syberię, m.in. śladami św. Rafała Kalinowskiego. Prymas Polski odwiedził wówczas liczne miejsca związane z dramatem zsyłek rodaków na „nieludzkiej ziemi”, aż po Władywostok (4-29 VII 1999 r.),

\section{Odpowiedzialność pasterska za Polaków i Polonię}

Ważnym znakiem odpowiedzialności kard. J. Glempa były liczne spotkania z rodakami w Rzymie czy w Warszawie. Prymas Polski chętnie podejmował $w$ rezydencji grupy pielgrzymkowe oraz turystyczne, umacniając rodaków w wierze oraz polskiej tradycji kulturowej. Aby podtrzymać więź, prymas kierował specjalne życzenia na te święta oraz liczne posłania na różne uroczystości czy rocznice.

Jako opiekun duszpasterstwa Polonii, prymas Polski w wielu krajach zawsze akcentował w swym przepowiadaniu oraz świadectwie odpowiedzialność pasterską Kościoła w Polsce za rodaków. Serdecznie odnosił się do polskich potomków, którzy nie posługują się już językiem ojczystym, ale za to niejednokrotnie ,czują" po polsku i cenią kulturę kraju pochodzenia swych przodków. Ważne jest - zwracał uwagę kard. J. Glemp - że wielu rodaków „nie wstydzi się być Polakami, a integrując się z krajem swojego zamieszkania i dla niego pracując, tym bardziej mogą być dumni, że pochodzą z narodu, który podejmuje się zawsze trudnych spraw, i jest przez to ceniony" (Charleroi, Belgia, 22 II 1987).

Świadomość „korzeni” pozostaje zawsze znakiem tożsamości, a ta daje odwagę na drogę ku przyszłości. Wobec tych wielorakich zobowiązań „wiemy, że potrzebne jest nam dzieło jednoczenia. W tym powitaniu odczuwamy duchową obecność wszystkich naszych Rodaków na całym świecie i Polonii w każdym kraju" (Gdańsk, 5 VI 1999 r.).

W prymasowskiej trosce o rodaków poza granicami nie może zabraknąć odniesienia do Matki Bożej, zwłaszcza z Jasnej Góry. Królowa Polski króluje w większości polonijnych domów, instytucji czy stowarzyszeń. Dlatego 
prymas Polski wskazywał: „Jasnogórskiej Matce zawierzamy wszystkich Rodaków, gdziekolwiek żyją na globie ziemskim" (Monte Cassino, Włochy, 18 V 1984 r.). Wizerunek Matki Bożej Częstochowskiej - uważał prymas -jest znakiem tożsamości narodowej oraz religijnej Polaków.

Warto jeszcze dodać, że kard. Józef Glemp odwiedził polskich misjonarzy pracujących w Algierii i na Wybrzeżu Kości Słoniowej (1987), a także w Papui Nowej Gwinei (1988). Modlił się z polskimi karmelitankami w północnej Norwegii (klasztor powstał z jego inicjatywy) i odwiedził członków polskiej wyprawy polarnej w ośrodku badawczym za Kołem Podbiegunowym na Spitsbergenie (1996).

Kardynał J. Glemp pamiętał o zmarłych Polakach, żyjących poza granicami ojczyzny. Nauczał m.in.: „Niewiasta szukająca zagubionej drachmy przywodzi nam dzisiaj na myśl także Matkę-Polskę, dostojną niewiastę, która szuka zagubionych dzieci. Jest ich bardzo dużo. Rozproszyli się po wszystkich kontynentach i nie sposób ich odnaleźć. Poszukiwania trwają długo, natrafiają na wiele przeszkód. Wymaga to cierpliwości, wytrwałości. Mijają lata, a poszukiwania ciągle trwają. Myślmy o tych wszystkich, którzy zginęli w sposób tajemniczy, nieudokumentowany albo z nieznaną dokumentacją w różnych miejscach" (Warszawa, 17 IX 1995 r.).

Za działalność na rzecz Polonii prymas Polski kard. Józef Glemp otrzymał 1 XII 2009 r. najwyższe, przyznawane przez „Wspólnotę Polską”, odznaczenie - Wawrzyn Polonijny. Było to symboliczne pożegnanie z kardynałem, który od 18 XII 2009 r. przestał pełnić posługę prymasa Polski, a tym samym opiekuna Polonii. Uroczystość odbyła się w siedzibie Stowarzyszenia „Wspólnota Polska” w Warszawie.

Prymas tak mówił o Polakach poza granicami: „To ważna część Polski, gdyż Polonia jest ważna i bardzo liczna, chociaż różnorodna. Niektóre ośrodki potrafią się organizować, dbać o siebie, o Kościól, ale część emigrantów stacza się też w bezideową pustkę. Są też konflikty między starą a nową Polonią, niekiedy nie mają wspólnego języka. (...) Nie musimy się też wstydzić naszej Polonii, gdyż na ogół jest pozytywnie nastawiona do spraw Polski, chrześcijaństwa, wychowania, zasadniczo rodacy szukają duchowości" (25 IX 2011 r.).

W testamencie prymasa Józefa Glempa znalazł się passus poświęcony jego posłudze polonijnej: „Moją pamięcią i modlitwą obejmuję naszych Rodaków na wszystkich kontynentach zamieszkałego Globu. Ich miłość do Polski niekiedy może nas zawstydzać, a oczekiwanie, że «Polska będzie Polską», jest potężne. Odwiedziłem nie tylko Rodaków, ale także kraje 
misyjne. Zawsze znajdowali się przyjaciele i ofiarni ludzkie, którzy finansowali moje podróże i wspomagali Polskę tak w potrzebach religijnych jak i kulturalnych".

Spotkanie różnych nurtów posługi prymasowskiej Józefa kardynała Glempa wpisało się w przebogatą dynamikę nowej ewangelizacji w Polsce i Europie, a w pewnym sensie w „znak Polonii” i w całym świecie. Prymas Polski stawał zawsze wobec Kościoła jako pastor gregis. To pasterz o wielorakim, bardzo bogatym doświadczeniu przewodzenia Kościołowi w Polsce. Bogactwo przemian społecznych i kulturowych oraz politycznych wyzwalało nowe świadectwa.

Warto przywołać słowa Papieża Benedykta XVI, który w liście po śmierci prymasa Józefa Glempa m.in. napisał: „Był sprawiedliwy, w duchu swego patrona św. Józefa. (...) Taka sprawiedliwość, pełna pokornego oddania woli Bożej, była fundamentem jego głębokiej miłości do Boga i człowieka, która była światłem, natchnieniem i mocą w trudnej posłudze przewodzenia Kościołowi w dobie znaczących przemian społecznych i politycznych, jakie miały miejsce w Polsce i w Europie. Ta miłość Boga i Kościoła, troska o życie i godność każdego człowieka sprawiły, że był apostołem jedności, a nie rozłamu, zgody, a nie konfrontacji, wspólnego budowania pomyślnej przyszłości w oparciu o przeszłe, podniosłe i bolesne doświadczeni Kościoła i Narodu. (...) Osobiście bardzo ceniłem jego szczerą dobroć, prostotę, otwartość i serdeczne oddanie sprawie Kościoła w Polsce i na świecie. Takim pozostanie w mojej pamięci i modlitwie. Niech Pan przyjmie go do swojej chwały" (24 I 2013 r.).

bp Andrzej F. Dziuba, Łowicz

\section{WIZYTY PAPIEŻA JANA PAWŁA II W BYŁYCH REPUBLIKACH ZSRR A STOSUNKI MIĘDZYETNICZNE}

Wszystkie republiki byłego Związku Radzieckiego, które papież Jan Paweł II odwiedził w latach 1993-2002 i w których żyją Polacy (Litwa, Łotwa, Estonia, Gruzja, Ukraina, Kazachstan), mają charakter mieszany narodowościowo i wyznaniowo, a w przypadku muzułmańskiego Kazachstanu, także i religijnie. Jego wizyty w tych republikach miały 
doniosłe znaczenie nie tylko religijne, lecz także narodowościowe. ${ }^{1}$ Nasuwa się pytanie o ich wpływ na relacje między Polakami a większością społeczeństwa innej narodowości, na postrzeganie Polaków przez nią oraz na jej postawy wobec nich. Niniejszy szkic jest próbą zapoznania się z tym zagadnieniem. Oparty jest na ponad trzydziestu odpowiedziach na ankietę rozesłaną na przełomie 2011 i 2012 r. pocztą mailową do osób ze środowisk inteligencji polskiej na Litwie, Białorusi, Ukrainie i w Kazachstanie, dotyczącą wpływu wizyt papieża Jana Pawła II na tożsamość narodową mieszkających w tych krajach Polaków. Wśród respondentów byli redaktorzy pism polskich, miejscowe nauczycielki języka polskiego, polityk, duchowni katoliccy, wśród nich abp Tomasz Peta z Kazachstanu, i inne osoby. Z tytułu swych funkcji i znajomości środowisk zarówno polskich, jak i innych, mieli oni stosunkowo szerokie pole obserwacji. Odpowiedzi na ankietę uzupełnia kilka wywiadów przeprowadzonych za pomocą poczty mailowej z kilkoma osobami z Ukrainy. ${ }^{2}$

Odpowiedzi na pytanie, czy i co po wizytach papieża zmieniło się w relacjach między Polakami, a większością społeczeństwa innej narodowości, są ostrożne i krytyczne. Tylko w jednym przypadku są zgodne i zdecydowane. Wszyscy respondenci stwierdzają bowiem, że w czasie wizyty papieża i spotkań z nim, panowała wśród ludzi różnych wyznań i narodowości atmosfera niezwykłej życzliwości i jedności.

Polka ze Lwowa (absolwentka Politechniki Lwowskiej) tak wspomina drogę na papieską mszę św. we Lwowie (26 VI 2001 r.) i nastroje wśród ludzi w tym dniu: „Szliśmy parę dobrych kilometrów. Cała ulica Stryjska we Lwowie - to był tłum ludzi z plakatami, śpiewem. Polacy, Ukraińcy, Rosjanie, trudno wymienić wszystkie narodowości. Nastrój podniosły, radość, właściwie życzliwość ogólna". Pojawienie się tego rodzaju pozytywnych uczuć (w zróżnicowanej narodowościowo i nierzadko skonfliktowanej społeczności) pod wpływem obecności papieża, i taka ich intensywność, było niespotykanym zjawiskiem. Ta sama respondentka podkreśla, że tego rodzaju uczucia i postawy osób różnej narodowości, wynikały z szacunku dla osoby papieża: „Środowisko, w którym się obracam jest międzynarodowe. Gdy zachodzi rozmowa o papieżu, każdy wypowiada się o nim

1 R. D z w o n k ow s k i, Papież Jan Paweł II. Spotkania z Polakami na Wschodzie 1993, 1999, 2001, 2002, Warszawa- Lublin 2005, s. 45-83.

2 Wywiady przeprowadzili: dr Oleg Gorbaniuk i dr Julia Gorbaniuk z KUL JPII. 
jak najlepiej - «Nasz Papież» - to określenie chyba wszystko tłumaczy”. Autorka tej wypowiedzi zwróciła uwagę na mało znany fakt, jakim było zatrzymanie się papieża przed zamkniętą w czasach sowieckich dawną katolicką katedrą ormiańską we Lwowie. Dzięki temu, po pewnym czasie, została ona zwrócona wiernym obrządku ormiańskiego.

Respondenci z Litwy i z Białorusi (znaczna część Polaków z tego kraju na spotkanie z papieżem $\mathrm{w}$ Wilnie przybyła specjalnym, przepełnionym pociągiem z Grodna), ${ }^{3}$ podkreślają zbliżenie Litwinów do Polaków w dniach jego wizyty na Litwie. Tłumaczą to niezwykłą osobowością papieża. Jeden z przybyszy z Białorusi pisze: „Znowuż to uczucie wspólnoty. Litwini byli bardzo życzliwi i, jak rzadko kiedy, wśród nich czułem się wówczas jak zupełnie wśród swoich" (Eugeniusz Lickiewicz). Redaktor ukazującego się w Wilnie kwartalnika „Znad Wilii”, Romuald Mieczkowski, wspomina, że pielgrzymka papieża na Litwę miała dla Polaków wielkie znaczenie, bo „dodała siły trwania na tej ziemi. Podczas pielgrzymki Polaków darzono serdecznością, zresztą narodowość wtedy nie była istotna - papież potrafił złączyć wokół siebie wszystkich”. Oczekiwania Polaków na Litwie związane z przybyciem papieża przedstawia następująco: „Mieliśmy nadzieję, że pielgrzymka zmieni optykę w stosunkach polsko-litewskich, doprowadzi do «realnego braterstwa», a przekładając to na konkrety, że Polakom np. zezwoli się na nabożeństwa po polsku (w określonych godzinach) w Katedrze Wileńskiej”. Tak się nie stało. Dalej stwierdza, że wizyta papieska w ni-

3 W dniach obecności papieża w Wilnie władze miasta bezpłatnie udostępniły komunikacje miejską (ks. J. Dziekoński). Polacy z Białorusi natrafiali na administracyjne przeszkody w udawaniu się na spotkanie z papieżem w samym Wilnie. Abp Kazimierz Świątek mówił na ten temat: „To rzecz dziwna, bo Litwa przyznała nam tylko 4 tys. zaproszeń na uroczystości religijne z udziałem Jana Pawła II w swoim kraju. Kiedy przyjechaliśmy, okazało się, że w poszczególnych parafiach jest jeszcze bardzo dużo zaproszeń. Ponieważ w poszczególnych parafiach na Białorusi zgłaszało się po 200-300 osób chętnych do udziału w pielgrzymce, my zaś mogliśmy zapewnić wyjazd tylko po jednym autobusie z parafii, przypuszczam, że ok. 15 tysięcy osób zostało zmuszonych do pozostania w domach. Szkoda, że ta okazja została zmarnowana. Na Łotwie nie było już żadnych ograniczeń, więc postanowiliśmy, że parafie znajdujące się bliżej granicy łotewskiej będą się tam kierować. Tu, w Agłonie, jesteśmy bardzo widoczni. Także przez łatwo zauważalne transparenty, przez flagi. A propos - w Wilnie była grupa wiernych z Polesia z transparentem «Zapraszamy do Pińska»"; Zapraszamy do Pińska. Z arcybiskupem Kazimierzem Świątkiem z Białorusi rozmawia Adam Hlebowicz, Ład 4/1993. 
czym nie zmieniła asymilacyjnej presji na Polaków. „Potem jednak życie na Litwie potoczyło się nie na korzyść Polaków litewskich - zdecydowanej ich większości nie oddano zabranej ziemi, nie rozwiązano problemu oryginalnej pisowni ich nazwisk, usiłuje się dotkliwie pomniejszyć zakres szkolnictwa po polsku, nie zezwala się na podwójne obywatelstwo, nie dofinansowuje się polskich placówek kulturalnych i in." Charakteryzując obecną sytuację, autor tej wypowiedzi dodaje: „Stosunek Litwinów do Polaków jest pełen nieufności, dążą oni ze wszech miar do zasymilowania ich na gruncie litewskości”.

Na podobne zjawisko zwraca uwagę redaktorka jednego z pism polskich ukazujących się w Wilnie („Tygodnik Wileńszczyzna”). Stwierdza, że wierząca część Litwinów zapewne zbliżyła się do Polaków, lecz nie są oni przez nich równoprawnie traktowani. „Współpracują ze sobą na płaszczyźnie religijnej: wspólne pielgrzymki, święta, katecheza dzieci. Gorsze - niestety, niejako odsuwanie czasem wiernych narodowości polskiej na stronę, np. w opracowaniu szlaku turystycznego «Śladami JP II na Litwie» nie znalazł się kościół Ducha Świętego, i inne” (Czesława Paczkowska).

Większych zmian po wizytach papieża w stosunkach między różnymi narodowościami nie dostrzegają też respondenci z Białorusi. Jest to dość zrozumiałe. W tym kraju nie było widocznych antagonizmów narodowościowych, polsko-białoruskich.

Nauczycielka z Brześcia, pisze: „Nasze otoczenie na mojej pamięci nigdy nie szanowało nas, jako Polaków. Pielgrzymki te dodały mocy wiary tym Polakom, których znam”. Zauważa jednak: „Odczuwałam, że niepolskie otoczenie bardzo zazdrości nam, Polakom, że mamy takiego papieża. Więcej tolerancji, więcej wiary. Pojawiła się duma z tego, że jestem Polką. Pielgrzymki papieża zmieniły moje postrzeganie siebie jako Polkę, dodały rozumienia prawdy o człowieku, o mojej osobie. Zaczęłam mniej obawiać się, jak mnie odbierano w społeczeństwie" (Hanna Paniszewa).

W innej odpowiedzi z Białorusi czytamy: „Może warto powiedzieć ogólnie, że choć powoli, ale jeżeli mówić np. o Białorusinach (którzy stanowią większość otoczenia dla każdego u nas Polaka), t a k si ę wy daje,ż e stosunek ich do Polski i do Polaków zmienia się na b a rd zi ej ra cjo n a l ny" (Eugeniusz Lickiewicz; podkreślenie autora wypowiedzi).

Zdaniem duszpasterza polskiego, pracującego od 1989 r. na Białorusi Wschodniej (archidiecezja mińsko-mohylewska), wybór Jana Pawła II, jego pielgrzymki do Polski i udział w spotkaniach z nim Polaków z tego kraju 
„spowodowały większe zbliżenie do siebie Polaków na Białorusi, dotychczas traktowanych jako «wrag naroda». Pod wpływem - jak pisze - tych wydarzeń zmieniło się myślenie na Białorusi, że Polska to rzeczywiście zagranica. Wcześniej mówiono zaś «kurica nie ptica, a Polsza nie zagranica». Polacy poczuli się dumni, ze swoich korzeni. Jan Paweł II poruszył świadomość religijną Polaków oraz świadomość narodową i sympatię, a nawet patriotyzm. Pielgrzymki spowodowały, że nawet niektórzy prawosławni, wcześniej nastawieni kontra katolików przez swoje partykularne władze religijne, zaczęli patrzeć [na Polaków] przez pryzmat Jana Pawła II, nie jako na wrogów, ale jako coś pozytywnego" (ks. Józef Dziekoński, wypowiedź z 16 II 2012 r.)

Opinie pochodzące z Ukrainy mają charakter bardziej zróżnicowany w zależności od tego, czy pochodzą z terenów za przedwojenną czy też za obecną granicą Polski. Śledzący przebieg wizyty papieża na Ukrainie redaktor gazety polskiej ukazującej się w Kijowie (Eugeniusz Tuzów-Lubański) pisze: „Nie było aż tak, że papieża oglądała cała Ukraina, jak to bywało w Polsce, bo jednak antywatykańska propaganda dała i swoje negatywne owoce w odbiorze Jana Pawła II. Tylko Lwów w odróżnieniu od Kijowa witał z całego serca papieża. (...) W Kijowie negatywne było to, że rozkazem prezydenta Kuczmy milicja pilnowała, aby nie dochodziło do bezpośrednich kontaktów zwykłych ludzi. Tysięcy milicjantów na ulicach denerwowały kijowian. Wzdłuż ulic stali nie tylko szeregowi milicjanci, ale nawet pułkownicy. I miasto wtedy wyglądało jak niby to wprowadzono stan wojenny. Natomiast we Lwowie wszystko było bardziej ciepłe i ludzkie i papież tu przemawiał w języku polskim, co było bardziej naturalne niż w Kijowie, gdzie mówił po ukraińsku.

Uczucia ludzi były na ogół dobre, oprócz niektórych ludzi wyznania prawosławnego. Zwłaszcza we Lwowie papieża przyjmowano jak kogoś dawno znanego i bliskiego. Papież jednoczył ludzi w dobrym i dawał nadzieję na lepsze życie. ${ }^{4}$ (...) Tylko Lwów w odróżnieniu od Kijowa witał z całego serca

$4 \quad$ Autor ma na myśli skrajnie negatywne stanowisko moskiewskiej Cerkwi prawosławnej wobec wizyty papieża na Ukrainie. Wywołała ona protest ze strony Patriarchatu Moskiewskiego, ponieważ papież przybył tam bez porozumienia z rosyjską Cerkwią prawosławną, która uważa Ukrainę za swoje „terytorium kanoniczne”. Patriarcha Aleksy II oświadczył publicznie, że „ta wizyta nie przyniesie niczego dobrego". Pozytywnie do wizyty papieża na Ukrainie nastawiony był natomiast Kościół Prawosławny Patriarchatu Kijowskiego i jego głowa, patriarcha Filaret; 
papieża (...) we Lwowie wszystko było bardziej ciepłe i ludzkie i papież tu przemawiał w języku polskim, co było bardziej naturalne niż w Kijowie, gdzie mówił po ukraińsku ${ }^{5}(.$.$) miejscowi Polacy byli od tej wizyty jakby$ wniebowzięci. To trudne do opisania, bo trzeba było patrzeć do oczu tych ludzi i z nich czytać. To było zdarzenie na miarę tysiąclecia, ale powtarzam, iż nie wszyscy Ukraińcy otworzyli własne serca na papieża".

$\mathrm{W}$ odpowiedziach na pytanie o relacje $\mathrm{z}$ innymi narodowościami po wizycie papieża jest mnóstwo stwierdzeń pozytywnych. „Powiem szczerze, czas zaciera odczucia. Było by na pewno gorzej dla pozycji Polaków Ukrainy w zakresie przestrzegania ich praw jako mniejszości narodowej" - pisze ten sam dziennikarz polski z Kijowa. Jego kolega z tego samego miasta, zastępca redaktora naczelnego „Dziennika Polskiego” (Borys Dragin) dodaje, że „wizyta papieża dodała Polakom otuchy, dał się zauważyć większy szacunek dla nich i łatwiej stało się im w otoczeniu być Polakami".

Nieco szerzej podobne opinie wyraziła Polka (lat 37) zza przedwojennej południowo-wschodniej granicy Polski. Na pytanie, co na Ukrainie byłoby inaczej, gdyby do wizyty nie doszło, odpowiada: „Pewnie pozostalibyśmy nadal w kompleksie i każdy walczyłby z innymi, z lęku przed utratą swojej religii, żeby nikt go nie nawracał na swoje. Papież pokazał nam, że jesteśmy jak mozaika, która tworzy piękny Boży obraz. To Bóg pomieszał nam języki - stworzył różnorodność w jedności dzieci Bożych. (...) Polacy poczuli się bardziej pewni i nawet dumni ze swojej wiary. Otrzymali dużo pochwał o papieżu jako wielkim Polaku. Polacy są bardziej aktywni i stają się otwarci na Polskę i kontakty z Polakami w kraju, może jeszcze mają swoje kompleksy z powodu języka, ale papież przywoływał Polaków do jedności całego narodu niezależnie, kto gdzie mieszka (Ameryka, Kanada czy Ukraina). Jesteśmy częścią narodu i musimy o tym pamiętać (...) nie wpadać w kompleksy. (...) Myślę, że (...) ludzie poczuli się mniej wyśmiewani za polskość (...), że jest więcej tolerancji między wyznaniami”.

zob. Władyka Markijan: O historii i dniu dzisiejszym Kościoła katolickiego na Ukrainie z księdzem biskupem Marcjanem Trofimiakiem rozmawia Włodzimierz Osadczy, Lublin-Łuck 2009, s. 158.

5 W Kijowie papież przemawiał także i po polsku (24 VI 2001). Było to krótkie rozważanie przed modlitwą „Anioł Pański”, po liturgii na lotnisku sportowym Czajka. W spotkaniu tym brało udział 150 tys. osób, w tym z Polski, Białorusi, Rosji, Węgier, Mołdawii, Gruzji; zob. G. Tu row s k i, J. S o s n ow s k a (oprac. i red.), Jan Pawet II dzień pod dniu. Ilustrowane kalendarium Wielkiego Pontyfikatu 1978-2005, fot. A. B u j a k, A. M a r i, t. II: 1991-2005, Kraków 2005, s. 1144. 
W odpowiedzi na pytanie, czy zmienił się stosunek otoczenia do Polaków, cytowana przed chwilą respondentka z Ukrainy ocenia: „Myślę, że nie. Stosunek otoczenia do nas wcale się nie zmienił. Natomiast osobom starszym teraz jest o wiele łatwiej przyznać się do polskości. Zdaje się, że wizyta Jana Pawła II stała się przełomowa również dla mentalności Polaków na Ukrainie. To był wyraźny znak, że już minęły czasy zastraszenia i terroru".

W odpowiedziach na pytania: Czy i jak wizyta papieska zmieniła postrzeganie przez Ukraińców ludzi innej narodowości? Co zmieniło się na lepsze, a co na gorsze? Jak pielgrzymka papieska wpłynęła na Polaków mieszkających na Ukrainie i co zmieniło się w ich postrzeganiu samych siebie? - padają przemyślane stwierdzenia: „Ukraińcy bardzo dobrze przyjęli Jana Pawła II. Tego papieża uwielbiają różne narodowości. Po wizycie, Polaków stali więcej szanować. A jeżeliby nie przyjechał wówczas, to wielu Ukraińców by nie mieli możliwości dostać jego błogosławieństwa. Przecież za granicę nie każdy potrafi pojechać (...). Polacy zawsze potrafią szanować swoich bohaterów narodowościowych. Szczególnie ci, którzy mieszkają poza krajem.

Tu, na Ukrainie, działalność Jana Pawła II była wielkim wsparciem dla Polonii. Był wzorcem dla milionów ludzi pochodzenia polskiego (...).

Otoczenie szanuje ludzi, a nie narodowości. Na moją narodowość nikt nie zwraca uwagi. Na mnie patrzą jako na człowieka, który postępuje w pewny sposób (...).

Wizyta papieża jeszcze raz udowodniła, że Polacy to wielka nacja. Otoczenie zawsze bardziej szanuje te narodowości, które wykazują wysoki poziom kultury. Proszę wziąć pod uwagę, że otoczenie może być różne i Polacy też (...) Jestem jeszcze bardziej dumna ze swojej narodowości” (Polka lat 30, Ukraina). Ostatnie zdanie tej respondentki, jest lejtmotywem wszystkich wypowiedzi osób deklarujących narodowość polską.

Charakterystyczna jest odpowiedź mężczyzny z okolic Kamieńca Podolskiego na pytanie, czy wizyta papieska spowodowała jakąś zmianę w stosunkach z sąsiadami innej narodowości. Wskazuje on na zgodne współżycie ludzi różnej narodowości w tej części Ukrainy. „Nie nic się zmieniło, żyjemy z sąsiadami jak dawniej, każdy w swojej wierze. U nas tu nie ma «nawiedzonych fanatyków», jest spokojnie. Może dla kogoś to jest bardzo ważne, są ludzie, którzy nawracają się do Kościoła, ale Kościół nie dzieli na Ukraińców czy Polaków, modlimy się wspólnie - jak rozmawiamy tak się modlimy". 
Dwaj respondenci z Ukrainy wspominają o pewnego rodzaju negatywnych skutkach wizyty papieża na Ukrainie. Chodzi o reakcję na nią wiernych Cerkwi prawosławnej. Kobieta lat 64 z diecezji kamieniecko-podolskiej pisze: „Pojawił się większy «rozbrat» z Ukraińcami wyznania prawosławnego i innego niż grekokatolickie. Ukraińcy byli nakręcani przez własne duchowieństwo, wielu było złych z powodu wizyty papieża jako niepotrzebnej i im zagrażającej. W niektórych przypadkach można to określić jako wrogość. ${ }^{6}$ To pozostało do dnia dzisiejszego. Część osób, która dawniej zapraszała z kolędą katolików (w czasie kolędy Polacy z Gródka [Gródka Podolskiego, diecezja kamieniecka] chodzą w grupach 15-20 osób i śpiewają u sąsiadów, a sąsiad prowadzi do sąsiada i tam śpiewa razem z innymi), teraz nie chce tego robić. Dla innych Ukraińców wizyta papieża była ciekawostką lub obojętna".

Mężczyzna lat 41 ze wspomnianej diecezji, w odpowiedzi na pytanie o wpływ przyjazdu papieża na relacje między międzywyznaniowe odpowiada: „Zmiany mogą być różne i «na plus», że bardziej są przyjaźni wobec katolików, i też «na minus». Wszyscy widzieli stosunek głowy moskiewskiego Kościoła do papieża. Ci, którzy byli przeciw, mogli bardziej upewnić się w swojej niechęci do katolików i mieć na to przyzwolenie swojej wspólnoty, popa".

Pracujący od dawna na Wołyniu ksiądz z Polski także wskazał na pogorszenie się, w następstwie wizyty papieża, stosunku do katolików „duchowieństwa prawosławnego obediencji moskiewskiej", ale także na jej bardzo pozytywne znaczenie dla Kościoła: „Wielu chce widzieć katolików jako poszczególne mniejszości, Polaków czy Węgrów. Mimo różnych zabiegów Kościół jest stygmatyzowany jako polski na Ukrainie Zachodniej czy węgierski na Zakarpaciu. Wielu naszych wiernych zobaczyło, że stanowimy pewną ilość i siłę, pewne bogactwo - wieloobrządkowość czy wielojęzyczność" (ks. Witold Kowałów).

W wypowiedziach z Ukrainy w sposób najbardziej wyraźny wyrażona została myśl, że wynikiem wizyty papieża było ukazanie ogółowi

6 Była ona niekiedy tak rażąca, że - jak wspomina organizator pielgrzymki papieża na Ukrainę ze strony Kościoła katolickiego rzymskiego obrządku, bp Markijan Trofimiak - świeccy wierni wyznania prawosławnego przepraszali go za niespotykaną wrogość jednego z hierarchów prawosławnych, który oświadczył, że modli się, by samolot z papieżem nie wylądował; zob. Władyka Markijan: O historii i dniu dzisiejszym Kościoła katolickiego na Ukrainie, s. 162. 
mieszkańców tego kraju obecności Kościoła katolickiego obydwu obrządków i jego światowego zasięgu oraz że tym samym dokonało się wzmocnienie jego pozycji i znaczenia w świadomości katolików Kościoła obrządku rzymskiego i greckokatolickiego.

Zwierzchnik grekokatolików, abp Swiatosław Szewczuk z Kijowa, w wypowiedzi dla Radia Watykańskiego z okazji dziesięciolecia wizyty Jana Pawła II na Ukrainie, ocenił ją jako pozytywny przełom w najnowszych dziejach katolików w tym kraju. Usunęła ona, jego zdaniem, pewne uprzedzenia w odniesieniu do osoby papieża, jak i Kościoła katolickiego. Przekonał on do siebie ludzi swą serdecznością i autentyzmem w głoszeniu Ewangelii. W swojej wypowiedzi arcybiskup stwierdził m.in.: „O tych osobistych spotkaniach z Janem Pawłem II Ukraińcy pamiętają do dzisiaj. Dziś wiedzą oni o Kościele katolickim i o grekokatolikach dużo więcej niż przed 10 laty. W wielu Ukraińcach dość długo utrzymywały się bowiem opinie zaszczepione przez sowiecką propagandę. Papież i Kościół byli po prostu wrogami ukraińskiego narodu. Stopniowo jednak Ukraińcy odkryli, że nie jest to żaden wróg, lecz wielki autorytet moralny i to nie tylko dla katolików, lecz dla wszystkich obywateli Ukrainy" (Radio Watykańskie, 16 V 2011).

Podsumowaniem wypowiedzi na temat wpływu wizyt papieża na stosunki międzyetniczne na Ukrainie może być opinia wspomnianego duszpasterza katolickiego obrządku łacińskiego z Ostroga na Wołyniu: „Niewątpliwie wizyta papieża Jana Pawła II dobrze wpłynęła na Polaków. W trakcie i po jej zakończeniu Polacy czuli się dowartościowani. Polacy są uważani za członków miejscowej społeczności, spotykają się z szacunkiem i respektowana jest ich godność, chociaż nadal istnieją stereotypy «Lacha», «białego Polaka» czy «jezuity». Po wizycie papieża te stereotypy nieco straciły na swojej sile. Szacunek do Polaków - spotykałem się z tym osobiście - był wyrażany także po śmierci papieża Jana Pawła II i po tragedii smoleńskiej" (ks. Witold Kowalów).

$* * *$

Opinie respondentów ankiety na temat relacji między ludźmi różnych narodowości i wyznań po wizycie papieża są realistyczne i trafnie oceniają rzeczywistość. Dostrzegają oni chwilowe zmiany pozytywne, niekiedy, ich zdaniem, są one nadal widoczne, czasem przewidują je w przyszłości, choć ma to charakter hipotetyczny, a niekiedy nie dostrzegają żadnych zmian. 
W Kazachstanie, gdzie ogółowi społeczeństwa kazachskiego Kościół katolicki jest nieznany, osoby Jana Pawła II nie kojarzono z Polską i z Polakami. Jego wizyta w tym kraju zmieniła tę sytuację w sensie korzystnym dla Polaków, a on sam został przez to społeczeństwo przyjęty z niezwykłą sympatią, szacunkiem i uznaniem. ${ }^{?}$

Roman Dzwonkowski SAC, Lublin

\section{ORZEŁ I LEW - POLACY W ETIOPII *}

Stosunki polsko-etiopskie to nie tylko obecność Polski w historii Etiopii, lecz również złożone konteksty geopolityczne i kulturowe składające się na motywacje Polaków powiązanych z Etiopią. A było ich wiele: obrona chrześcijaństwa, chęć poznania świata, działalność misyjna, żądza bogactwa, zainteresowania badawcze, poszukiwanie kontaktów handlowych i dyplomatycznych oraz wojny. Byli to ludzie różnego temperamentu i zawodu: dyplomaci i misjonarze, naukowcy i artyści, eksperci i podróżnicy, dziennikarze i żołnierze.

Po pierwsze, zainteresowanie Polaków Etiopią, od zarania wzajemnych stosunków, nie miało aspektu praktycznego, albowiem Polska nigdy nie miała zamorskich kolonii. Międzywojenne ambicje kolonialne polskiej Ligi Morskiej i Kolonialnej ówczesny minister spraw zagranicznych RP, Józef Beck (1984-1944), ironicznie skomentował w swoim pamiętniku: ,... moim zdaniem, kolonie polskie zaczynają się już w Rembertowie [tj. na wschodnich przedmieściach Warszawy].” Po drugie, napływ Polaków do Etiopii nigdy nie miał też charakteru falowego. Wielu Polaków, zaplątanych w wir wydarzeń historycznych albo w wyniku własnych świadomych wyborów, związało swoje losy z Etiopią. Pierwszymi Polakami, o jakich wiemy, którzy osiedli w Etiopii na stałe byli: kupiec zajmujący się eksportem skór i kawy, przedsiębiorca, ajent handlowy, inżynier budowy dróg w służbie cesarza Haile Selassie, lekarz wojskowy oraz dziennikarz. Wszyscy oni przebywali w Etiopii w przededniu wojny etiopsko-włoskiej. Powojenne

7 R. D z w o n k ow s k i, Papież Jan Pawet II. Spotkania z Polakami na Wschodzie, s. 77-87.

* Autor niniejszego artykułu, Jarosław Szczepankiewicz, w latach 2008-2012 był Ambasadorem Nadzwyczajnym i Pełnomocnym Rzeczypospolitej Polskiej w Federalnej Demokratycznej Republiki Etiopii. 
losy większości z nich nie są znane. Pamiątką udziału Polaków w walkach na afrykańskim froncie II wojny światowej są nagrobki polskich żołnierzy na cmentarzu alianckim w Asmarze. W 1951 r. przyjechała do Addis Abeby czterdziestoosobowa grupa przesiedleńców z obozów w Niemczech Zachodnich z zamiarem zajęcia się rolnictwem w słabo zaludnionych regionach Etiopii. Część osób nie zdecydowała się jednak osiedlić w i opuściła Etiopię, pozostali lepiej lub gorzej próbowali ułożyć sobie życie.

\section{Polsce służyć, świat rozumieć!}

XX-wiecznym rysem charakterystycznym dla polskiej obecności w Etiopii było zaangażowanie się Polaków we współpracę naukowo-techniczną, odpowiednik dzisiejszej pomocy rozwojowej. Eksperci z Polski zatrudnieni byli na etiopskich uczelniach, doradzali w opracowywaniu strategii rozwojowych, angażowani byli jako eksperci przez międzynarodowe instytucje zajmujące się wsparciem rozwoju Etiopii. Przybywali też dyplomaci, artyści, dziennikarze, misjonarze i wojskowi. Polacy powiązani z Etiopią pozwalali zrozumieć historię i realia tego kraju nie tylko nam, Polakom, ale, co najważniejsze, samym Etiopczykom. Byli i są wśród Polaków w Etiopii tacy, którzy wnieśli duży wkład w kształtowanie etiopskiej administracji państwowej, systemu finansowego i szkolnictwa, a także zacieśniania polsko-etiopskich więzi. Wszyscy ci niezwykli ludzie przez całe swoje życie utrzymywali emocjonalne więzi z Etiopią budując pomost porozumienia pomiędzy Polakami i Etiopczykami. Wymienię tylko najbardziej zasłużonych na tym polu:

Stanisław C h o j n a c k i (1915-2010) - profesor, światowej sławy etiopista, kulturoznawca, jeden z najwybitniejszych badaczy etiopskiej sztuki. Autor kilkudziesięciu publikacji o etiopskiej sztuce, szczególnie interesował się ikonografią. Mieszkał w Etiopii przez 26 lat, od 1950 r. Był szefem najpierw biblioteki University College of Addis Ababa, a w chwili założenia Instytutu Studiów Etiopistycznych przeniósł tam jej etiopistyczne zbiory i zorganizował muzeum, które od 2010 r. nosi jego imię i można je zwiedzać do dziś. Razem z założycielem Instytutu, Richardem Pankhurstem, wydawał ,Journal of Ethiopian Studies”. W 1970 r. cesarz Haile Selassie odznaczył go „Gwiazdą Etiopii”. Po rewolucji 1974 r. zamieszkał w Kanadzie.

Witold Grabowski (1898-1966) - prawnik, prokurator Sądu Apelacyjnego w Warszawie, minister sprawiedliwości oraz senator RP w latach 1938-1939. Po 1945 r., w randze majora, był zatrudniony w brytyjskiej 
administracji w Erytrei. Przez wiele lat pracował jako sędzia w Etiopii; był szefem Wydziału Kryminalnego Sądu Najwyższego. Pełnił funkcję wiceprzewodniczącego etiopskiego Sądu Najwyższego. Uczestniczył w kodyfikacji etiopskiego prawa i był jednym ze współtwórców etiopskiej konstytucji w czasie panowania Haile Selassie I. Wykładał na Uniwersytecie w Addis Abebie. W latach 50. XX w. jeden z bardziej znanych cudzoziemców w Etiopii, cieszący się dużym zaufaniem cesarza, odznaczony za zasługi najwyższym orderem - „Gwiazdą Etiopii”. Od 1957 r. mieszkała z nim w Etiopii jego żona, Irena, która dotąd pracowała w USA m.in. w Sekcji Polskiej Rozgłośni „Głos Ameryki” i współtworzyła Instytut Józefa Piłsudskiego w Nowym Jorku. W maju 1966 r. przenieśli się na stałe do Wielkiej Brytanii.

Aleksander K o n t o r ow i c z (1900-?) - polski skrzypek, profesor Konserwatorium Muzycznego w Wilnie. Wyemigrował do Kairu, gdzie w latach 1934-1944 był profesorem w Królewskim Instytucie Muzycznym i na Wydziale Muzycznym Uniwersytetu Króla Fouada I. Uczył tam gry znaną etiopską skrzypaczkę, Yewebdar Gebrou. W 1944 r. wyjechał do Addis Abeby, a cesarz Haile Selassie I uczynił go dyrektorem muzycznym orkiestry gwardii cesarskiej i nadwornym skrzypkiem odpowiedzialnym za organizowanie w pałacu cesarskim, w latach 1944-1948, wieczorów poświęconych muzyce klasycznej. Był także, od 1941 r., dyrektorem pierwszej w Etiopii szkoły muzycznej - National School of Music w Addis Abebie. Profesor miał ogromny wpływ na rozwój powojennej muzyki nowoczesnej w cesarstwie.

Wacław K o r a b i e w i c z (1903-1994) - lekarz, podróżnik i etnograf. Trafił do Etiopii w 1955 r. zatrudniony jako lekarz przez Ministerstwo Zdrowia w szpitalu w Gore. Swoje wspomnienia z Etiopii, przeplatane etiopską historią i kulturą, opisał w książce Stońce na Ambach. Zainteresował się krzyżami noszonymi przez etiopskich mnichów i studiował ich symbolikę. Cesarz Haile Selassie umożliwił mu wydanie w Etiopii albumu poświęconego krzyżom. Zebrał sporą ich kolekcję, którą przywiózł ze sobą do Polski i podarował Muzeum Narodowemu w Warszawie, gdzie wciąż można jĄ oglądać.

Jerzy (George) K r ze c z u n ow i c z (1908-?) - prawnik, założyciel Katedry Prawa na Uniwersytecie w Addis Abebie. Na podstawie polskiej legislatury opracował kilka kodeksów prawa etiopskiego oraz komentarzy do niego. Wieloletni doradca rządu cesarskiego i wykładowca kilku pokoleń 
etiopskich prawników. Opuścił Etiopię po wybuchu rewolucji i osiedlił się w Szwajcarii.

Bogodar W in i d (1922-1996) - profesor geografii UW, specjalizował się w krajach rozwijających się, zwłaszcza afrykańskich. Choć nie spędził w Etiopii życia, bo zaledwie przez 5 lat wykładał na Uniwersytecie im. Haile Selassie I, był wielkim miłośnikiem Etiopii, podziwianym i uwielbianym przez studentów. Podczas swojego pobytu wtopił się w etiopską śmietankę towarzyską, nawiązując znajomość nawet z samym cesarzem. Jest jednym z najbardziej znanych na świecie polskich geografów.

\section{Polacy dzisiaj - misjonarze piękna, prawdy i pokoju}

Żyć samą sztuką - to wielka sztuka dla artysty

Barbara G o s hu jest artystką malarką, absolwentką Akademii Sztuk Pięknych w Krakowie. Razem ze swym mężem, Worku, już od 41 lat mieszka i tworzy w Addis Abebie. „Z ogromną ciekawością pojechałam do kraju mojego męża, słysząc o nim bardzo wiele już wcześniej. Mój dziadek opowiadał mi historie z czasów wojny włoskiej i o tradycjach chrześcijańskich, które z Etiopii się wywodzą, no i przepiękne opowieści o królowej Sabie i królu Salomonie. Kiedy przyjechałam do Etiopii, to wszystko tak bardzo mnie zniewoliło i pochłonęło, że zawsze tam maluję i staram się rozsławiać imię Polski po całym świecie. Próbuję czasy minione związać z dzisiejszymi. Wprowadzić jakiś pomost między tym, co stworzyła Etiopia niezwykłego w ikonografii i zbliżyć to do czasów dzisiejszego człowieka".

Już podczas studiów w Krakowie Barbara zachwyciła się pięknem starochrześcijańskich ikon. Po przyjeździe do Addis Abeby początkowo zarabiała na życie malowaniem portretów, ale już wkrótce, w 1972 r., wraz z mężem, absolwentem School of Fine Arts w Addis Abebie i Akademii Sztuk Pięknych w Krakowie, zorganizowali wystawę swojego malarstwa sakralnego. Otworzył ją sam cesarz Haile Selassie I. Wystawa była prawdziwym wydarzeniem w Addis Abebie - zaproszono na nią całą międzynarodową śmietankę towarzyską stolicy. Od tamtej pory państwo Goshu wystawiali swoje dzieła na wszystkich kontynentach, a ich obrazy trafiły niemal do każdego kraju świata. Ten początkowy sukces pozwolił im na resztę życia poświęcić się sztuce. Barbara wyspecjalizowała się w malarstwie etiopskich ikon na drewnie i kamieniu, a Worku przez prawie 30 lat wykładał w The School of Art and Design of Addis Ababa. 
W latach 90. XX w. państwo Goshu otworzyli w Addis Abebie galerię, The Goshu Art Gallery, w której można oglądać zarówno ich malarstwo jak i obrazy młodych artystów, studentów Worku, którym małżeństwo pomaga w ten sposób w autopromocji. Galeria posiada również dzieła o muzealnej wartości - zbiory The Sacred Art of Ethiopia, nagromadzone przez 40 lat, które miały swoją roczną objazdową ekspozycję w Hiszpanii.

Jednocześnie Barbara i Worku stworzyli ciepły, pełen gości dom w Addis Abebie, gdzie swojsko czuje się zarówno Polak, jak i Etiopczyk. W duchu polsko-etiopskiej dumy i patriotyzmu wychowali też swoje dzieci: „Mój mąż jest bardzo z Polską związany. Jak już raz tu przyjechał, to przepadł na zawsze. Mamy dwie ojczyzny, a nasza rodzina pochodzi z wielu rozmaitych krajów. Tworzymy takie United Nations". Oboje co roku przyjeżdżają do Krakowa, żeby naładować duchowe baterie. Tu, w krakowskiej galerii Lidii Żukowskiej „Kocioł Artystyczny”, można oglądać ich malarstwo.

W 2000 r. minister spraw zagranicznych Polski, Władysław Bartoszewski, wyróżnił Barbarę Goshu dyplomem za wyjątkowe osiągnięcia w promowaniu Polski w świecie. W 2012 r. minister kultury, Bogdan Zdrojewski, uhonorował Barbarę Goshu Srebrnym Orderem za Zasługi dla Kultury Gloria Artis.

Szkło nigdy nie blednie

Barbara Parker (wcześniej Barbara Tkacz-Tesfaye) jest absolwentką Akademii Sztuk Pięknych we Wrocławiu, wszechstronną artystką specjalizującą się w ceramice, malarstwie, grafice i wyrobach ze szkła artystycznego.

Do Etiopii przyjechała krótko przed rewolucją w 1974 r., razem z mężem Etiopczykiem, którego poznała i poślubiła w Polsce. Od początku związana jest z Hotelem Hilton w Addis Abebie, dla którego realizowała wiele projektów artystycznych, i od lat prowadzi sklep z własnymi pracami. W 1996 r. założyła Artistic Glass Centre, w którym zatrudnia głuchoniemych rzemieślników wyrabiających witraże i drobne rękodzieło według jej projektów. Firmę prowadzi razem z mężem, inżynierem, który doradza jej, jak montować wielkie witraże okienne. „Ja się właściwie nie reklamuję. Ludzie tutaj mówią jeden drugiemu. Dla mnie ważne jest to, co robię, a nie za ile to robię. Chodzi bardziej o to, żeby siebie wyrazić, niż aby zarobić pieniądze. Może właśnie dlatego artyści odnoszą w Etiopii sukces?”

W chrześcijańskiej Europie witraże pojawiły się w średniowieczu i szybko rozpowszechniły w gotyckim budownictwie sakralnym, gdzie 
zdobiły przestronne okna strzelistych kościołów. Dzięki barwionym kolorowo szkłom światło padające do wnętrza było stłumione, co pogłębiało doznania duchowe wiernych. Witraże, które przedstawiały sceny i symbolikę biblijną, pełniły przede wszystkim funkcję dydaktyczną. Do Polski technika ta dotarła w XIV w. Pierwsze witraże pojawiły się w Krakowie, a ich najbardziej znanym XIX-wiecznym twórcą jest Stanisław Wyspiański, który za prace dla kościoła Mariackiego otrzymał prestiżową nagrodę Akademii Umiejętności. Współcześnie witraże wykonywane są tą samą technika co wieki temu, ale coraz częściej jako sztuka użytkowa spełniają indywidualne potrzeby zamawiających.

Barbara Parker jako pierwsza w Etiopii zaczęła używać szkła artystycznego na szeroką skalę. Zaczęło się od zwykłego przypadku - znajoma opuszczająca Etiopię sprzedawała szkło - a zakończyło wielkim sukcesem - jej prace zdobią nie tylko prywatne domy w wielu zakątkach świata, rezydencje ambasadorów i siedziby ważnych instytucji, ale przede wszystkim wiele etiopskich kościołów, np. kościoła św. Jana w Addis Abebie czy św. Marii w Wukro, a w kościele w Debre Dammo jedna ze ścian wyłożona jest kaflami z motywami zwierzęcymi jej produkcji. Inspiracje czerpie z etiopskiej przyrody, kultury i historii, często pojawiają się w jej pracach motywy religijne. Witraż to skomplikowana technika wymagająca dużego doświadczenia i umiejętności. Polka wyspecjalizowała się w wielu stylach: malowania na szkle, piaskowania, naklejania, wtapiania i łączenia szkła z metalem. Stosuje ponad 65 różnych kolorów. Szkło nigdy nie blednie, a zatem, choć Barbara nie organizuje wystaw swoich prac, bo sprzedają się na bieżąco, jej dzieła pozostaną trwale przez pokolenia i będzie je mógł podziwiać każdy wierny, odwiedzający etiopskie kościoły.

Polka łączy pracę artystyczną i społeczną. We współpracy z ośrodkiem opiekującym się niepełnosprawnymi poszukuje osób uzdolnionych artystycznie, bo jak mówi, do zrobienia witraża wystarczy mieć sprawne ręce, dobre oczy oraz talent. A wiele talentów drzemie tam, gdzie się ich nie spodziewamy. Po treningu, podczas którego sprawdza umiejętności kursantów, Barbara proponuje niektórym z nich pracę. W ten sposób oferuje osobom pozbawionym możliwości zarobkowania, często proszącym o wsparcie na ulicy, unikalną szansę nie tylko samodzielnego utrzymania się, ale również wyrażenia siebie i doskonalenia zawodowego pod okiem mistrza. Po kilkuletniej pracy niektórzy z nich gotowi są odejść i założyć własną działalność rzemieślniczą. 
Takie łączenie pracy artystycznej i społecznej jest dziś często stosowane w projektach współfinansowanych ze środków europejskich. Polska, od 7 lat kraj członkowski Unii Europejskiej, jest obecnie jednym z największych beneficjentów Europejskiego Funduszu Społecznego, który pozwala na wspieranie różnego rodzaju aktywności z udziałem niepełnosprawnych, w tym aktywności artystycznej. Barbara Parker udowadnia, że takie działania są skuteczne również poza Europą i możliwe nawet bez finansowego wsparcia. Ważne jest zaangażowanie i twórczy talent. Sztuka może nie tylko cieszyć oko i zaspokajać „wyższe potrzeby” człowieka, ale także być znakomitą terapią i pomysłem na życie.

Godna przyszłość

Zgromadzenie Misyjne Sióstr Służebnic Ducha Św i ęt e go prowadzi działalność misyjną i rozwojową w Etiopii od listopada 1994 r. Dwadzieściasióstr zakonnych z wielu krajów świata, w tym trzy Polki (s. Anna Trzepacz, s. Fabiola Lech i s. Judyta Ligięza), prowadzi domy w Alemtena, Waragu, Badessa, Chole, Wolisso i Addis Abebie.

Działalność zgromadzenia, oprócz ewangelizacji, obejmuje szkolnictwo podstawowe, programy alfabetyzacyjne dla dzieci i młodzieży, a także projekty wspomagające edukację dziewcząt i sierot oraz dzieci z rodzin zakażonych wirusem HIV. Ponadto siostry oferują bezpłatne poradnictwo medyczne, wykonywanie szybkich testów i wsparcie dla osób zakażonych wirusem HIV. Prowadzą przychodnie, kliniki, szpitale oraz ośrodki zdrowia $\mathrm{w}$ trudno dostępnych terenach. Zgromadzenie zorganizowało leprozoria, zajmuje się narkomanami, działa w obozach dla uchodźców. Siostry włączają się też w działalność w sferze rolnictwa i hydrologii.

Siostra Judyta Ligięza: „Jesteśmy posyłane zwłaszcza tam, gdzie człowiek cierpi. Polityka państwowa sprawia, że w całokształcie naszej obecności misyjnej w Etiopii projekty rozwojowe stały się naszym głównym zajęciem. Wierzymy, że nasza obecność może wnieść trochę nadziei, że przyszłość może być inna, godniejsza".

Świat chce uniknąć drugiej Rwandy

Andrzej Grzelka jest pułkownikiem polskiej armii w stanie spoczynku, absolwentem cybernetyki w Wojskowej Akademii Technicznej, $\mathrm{PhD}$ w zakresie obrony powietrznej. Pracował w wielu jednostkach Wojska Polskiego, a po obronie doktoratu wykładał w Akademii Obrony Narodowej w Warszawie - najwyższej rangą polskiej uczelni wojskowej. „Ale ciągnęło 
mnie w świat, chciałem zobaczyć, co robią inni, chciałem dowiedzieć się, jak działają misje pokojowe". Zaczęło się od Iraku. Tam w latach 90. XX w. służył w dwóch krótkich misjach UNSCOM (UN Special Commission), których zadaniem było poszukiwanie broni masowego rażenia. Następnie został szefem logistyki w ramach misji pokojowej ONZ, MINURSO (Mission des Nations Unies pour l'Organisation d'un Référendum au Sahara Occidental). Jej mandat zakładał utrzymywanie zawieszenia broni w konflikcie POLISARIO-Maroko i organizację referendum o samostanowieniu dla Sahary Zachodniej.

W 2000 r. rozstał się z wojskiem i został cywilnym pracownikiem ONZ. „Każdy szuka możliwości rozwoju. To był czas restrukturyzacji w polskiej armii, więc uznałem, że to może być szansa na mój osobisty rozwój i wyszedłem z wojska".

Dzięki doświadczeniu zdobytemu na Saharze Zachodniej otrzymał stanowisko logistyka w UNMEE (United Nations Mission in Ethiopia and Eritrea). Był odpowiedzialny za zabezpieczanie wojska i pracowników cywilnych ONZ po obu stronach granicy. W Erytrei przebywał 5 lat, od 2000 do końca 2005 r., kiedy znalazł się w Addis Abebie. Ze względu na znajdującą się tu siedzibę Unii Afrykańskiej otrzymał pracę w UN Assistance Cell to the African Union. Doradzał UA w zakresie logistyki przy prowadzeniu misji pokojowej AMIS (African Mission in Sudan) w Darfurze.

Niedawno utworzona została w Addis Abebie nowa komórka ONZ - UN Office to African Union, dla której Andrzej Grzelka doradza logistycznie w ramach AU Peacekeeping Support Team. Komórka ta wspiera UA w tworzeniu tzw. African Standby Forces - pokojowych sił afrykańskich gotowych do użycia w przypadku turbulencji w Afryce.

Takie siły to nowy pomysł na utrzymywanie przez UA porządku w Afryce. ONZ ma wciąż ważną rolę do odegrania na świecie, jest finalnym partnerem w grze o pokój, ale liczy na pomoc organizacji regionalnych, zwłaszcza w Afryce, gdzie zlokalizowana jest większość misji pokojowych. Unia Afrykańska ma być zatem regionalnym partnerem ONZ. Przewagą UA w szybkim organizowaniu misji pokojowych jest nowoczesny system głosowania większościowego. ONZ, aby podjąć misję, musi mieć zgodę całej piątki Rady Bezpieczeństwa. W UA żadne państwo nie może zablokować operacji pokojowej. Ponadto ONZ, aby uruchomić misję pokojową, musi zwrócić się do poszczególnych państw o wysłanie wojsk we wskazany rejon. Potrzeba dużo czasu, by zmobilizować siły. Świat wyciąga wnioski i chce uniknąć tego, co stało się w Burundi i Rwandzie. 
„Unia Afrykańska będzie miała Standby Forces gotowe do użycia na zasadzie lokacyjnej - w ciągu dwóch tygodni 2500 wojsk ma osiągnąć dowolny punkt w Afryce, aby zapobiec nieszczęściu. W tej chwili ONZ takich sił nie ma. Unia Afrykańska będzie mieć lepszy system już w 2015 r. Pracujemy razem i doradzamy, jak to zrobić. Unia Europejska i inne państwa na świecie, jak USA, Brazylia i Kanada popierają ten projekt i finansują go".

Jarosław Szczepankiewicz, Warszawa 